Александра Савић

Удружење лектора

Републике Српске

Самостални истраживач

aleksandra.suvira@yahoo.com
811.163.41:004.738.5

https://doi.org/10.18485/ai_lik.2019.5.8.4

Оригинални научни рад

\title{
ЈЕЗИК И ДИГИТАЛНЕ ТЕХНОЛОГИЈЕ У РЕПУБЛИЦИ СРПСКОЈ
}

У раду се разматра однос српског језика и дигиталних технологија, као и тренутно стање у Републици Српској када је у питању дигитализација ове области. Наиме, у овом босанскохерцеговачком ентитету постоје назнаке опредјељења за иновативније приступе језику и настави, али још увијек немамо стратешке документе који то поље уређују. Са друге стране, наилазимо на одређене појединачне напоре у спајању нових технологија и језика, а један од таквих примјера свакако је и мобилна и веб-апликација Јайолої коју су израдили Удружење лектора Републике Српске, студенти Универзизтета у Бањој Луци и компанија Ланако, и која може бити примјер успјешног приватно-јавног парнерства.

Кључне ријечи: Јaӣолоі̄, апликација, Удружење лектора Републике Српске, Ланако, дигиталне технологије

\section{1. Увод}

Дигитализација је, не само када су у питању језици, него и многе друге области човјековог живота и дјелања, постала неопходан и неизоставан процес у савременом добу. Њено увођење је досад показало многобројне предности као што су чување података, убрзавање процеса рада, еколошка предност над традиционалним методама рада итд. Што се језика тиче, позитивне стране употребе напредних технологија свакако су лакши и бржи приступ материјалима, похрањивање великих база података на једном мјесту, брисање језичких 
и других граница, могућност повезивања језика са другим креативним пословима, олакшано учење, примјена напреднијих методичких алата у настави и образовању и многе друге, што све зависи од области језика која се дигитализује. У публикацији Срйски језик у gиіитиалном gобу (1-3), аутори наводе сљедеће предности кориштења језичких технологија у вишејезичној Европи, чији је дио и српски језик: примјена ових метода омогућава савладавање језичких препрека и њеним коришћењем се брише јаз међу европским језицима и то тако што апликације високог квалитета олакшавају учење страних језика.

Што се тиче српског језика, његове граматичке, правописне и стилске специфичности захтијевају посебан приступ и код избора и код начина дигитализације, као и код било код другог језика, зато што се употреби информационих алата ријетко може приступити преносећи рјешења из једног језика у други. Ово су језичке технологије које се најчешће користе - „исправљање правописних грешака, подршка састављању текста, рачунарски потпомогнуто учење језика, претраживање информација, екстракција информација, одговори на питања, резимирање текста, препознавање говора и синтеза говора“" (Срйски језик у gиїитиалном gобу: 20). Нажалост, још увијек не постоји општи документ или стратегија којом се уређује и описује ова област у нашем језику, дакле узимајући у обзир интегрални српски језички простор, па је тако највећи помак у кориштењу напредних технологија направила Србија, управо тако што је и сама дио већих европских пројеката или интердисциплинарним приступом овој теми, односно сарадњом између научних институција.

\section{1. Стање у Републици Српској:}

Када говоримо о Републици Српској, једна од области у којој је дигитализација најуспјелија и најочигледнија свакако је библиотечка дјелатност јер наше библиотеке прате рад библиотека у Србији и тиме не само да иду у корак са трендовима него својим читаоцима пружају бољу и бржу 
услугу. Недавно је у овом ентитету покренута и дигитализација уџбеника географије коју је Министарство просвјете и културе израдило у виду пилот-пројекта послије кога би требало да овај процес прате и многи други предмети како би се ученицима и наставницима понудио нови поглед на знање и учење који ће унаприједити интерактивну наставу. На страницама надлежних министарства, читамо јасну намјеру за повезивањем учења, школа, универзитета и библиотека са дигиталним технологијама и жељу за интер-

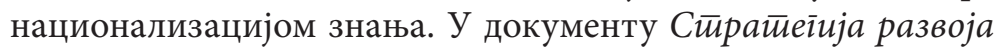
кулйуре Рейублике Срӣске 2017-2022, у дијеловима публикације „Кључни изазови у области“, наглашава се потреба дигитализације културних добара, библиотечке, аудио-визуелне и музејске грађе те кључних публикација. Што се језика и писма тиче, јасно се истиче опредјељење за њихову заштиту, очување и промоцију. Међутим, још увијек се не спомиње дигитализација, иако је на овогодишњем Форуму о ћирилици истакнута потреба за увођењем напредних технологија и у област језика. С обзиром на наведено, ипак је видљив велики помак у односу на претходне године, те се употреба напредних технологија виђа спорадично и то најчешће у виду методичких иновација и то као индивидуални напор креативних појединаца. Један од таквих покушаја повезивања језичких и

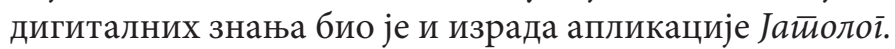

\section{2. Мобилна и веб-апликација Јатолог}

Без обзира на то што су посједовали скромно знање о дигитализацији, чланови Удружења лектора Републике Српске одлучили су да њихов први пројекат буде управо повезивање језичких знања са напредним технологијама. Прије него што је пројекат покренут и подржан од стране надлежних институција, требало је пронаћи и партнера у привреди, управо зато што је Јайолої имао двоструку улогу - с једне смо стране хтјели комерцијализовати апликацију коју ћемо креирати, а са друге је било јако важно поштовати научне методе приликом њене израде, и то све како бисмо јој 
омогућили - вјеродостојност, приступачност и једноставно руковање.

\section{1. Приватно-јавно партнерство}

Нажалост, језик је поље које је тешко поставити у оквире профитно опредјељеног окружења, али неке друштвено одговорне компаније увијек су спремне подржати напоре за очувањем језика, поготово ако је у питању иновативан приступ пројекту. Такође, ова област је још у повоју чак и у већим земљама, па је изузетно тешко и скупо приступити примјени најновијих технологија само у оквиру научне заједнице која сама нема ни довољно знања ни ресурса за такве кораке. Сарадња привреде и научно-истраживачких центара одавно је позната у окружењу и чини се као добар спој у којој обје стране имају корист. Овај пројекат подржала је бањалучка компанија Ланако а поред Удружења лектора Републике Српске, у изради апликације учествовали су и Филолошки и Електротехнички факултет у Бањој Луци.

Ако говоримо о обостраном задовољству у случајевима приватно-јавног партнерства, можемо нагластити да су и једна и друга страна испуниле предвиђене циљеве. У случају приватне компаније, биле су очекиване сљедеће добити - најприје је то бесплатна промоција, с обзиром на то да се радило о пројекту који је био не само институционално него и медијски подржан, а ако говоримо о приватним предузећима, знамо да су промоције које предузеће приказују у другачијој улози изузетно цијењене и вредноване више од класичних реклама. Такође, запослени у компанији проширили су своја знања и интересовања али и омогућили студентима на пракси да учествују у интердисциплинарном истраживању. Такође, стекли су искуство у дигитализацији језика која код нас још увијек није на завидном нивоу, али можемо очекивати више пројеката на том пољу у будућности.

Аго говоримо о интересу Удружења лектора Републике Српске, ми смо добили најприје бесплатну опрему и помоћ стручњака у области информационих технологија те израду 
дигиталне базе, потпуно бесплатно. Такође, компанија Ланако омогућила нам је дизајнерске и маркетиншке услуге које су радили изузетни стручњаци, па су њихови запослени, заједно са чллановима Удружења, осмислили лого апликације, креирали маркетиншки план и организовали велику промоцију догађаја на којој је јавности представљена апликација.

\section{2. Методски поступак}

Као што је претходно истакнуто, база података ијекавских облика ријечи састављена је уз поштовање свих научних принципа и методских поступака. Прво, она је оригинално дјело, састављено искључиво за потребе ове апликације. Друго, ради се о бази направљеној на основу издања у Републици Српској и то из различитих области, чиме смо хтјели не само да промовишемо ове публикације него да издвојимо најфреквентније ијекавске облике, како бисмо базу података учинили што кориснијом.

Кориштена су сљедећа издања:

1. Бранко Ћопић „Башта сљезове боје“, АСК.

2. Бранко Ћопић „Доживљаји мачка Тоше“, АСК.

3. Ранко Поповић (2009), ,Чин препознавања““.

4. Годишњак Друштва чланова Матице Српске у Републици Српској 2/2012.

5. „Значај српског језика и књижевности у очувању идентитета Републике Српске“, Филозофски факултет Пале, (2015).

6. Милорад Телебак (2004), Практични језички савјетник“.

7. Независне новине (20-27.3.2018)

8. Мондо Бих - интернет портал (јануар-април 2018)

9. Устав Републике Српске

10. Закон о Фонду солидарности (Савић, 2018: 743)

Сама израда састојала се из два одвојена процеса - прво је израђивана база података коју је Удружење предало ИТ стручњацима, како би они приступили техничкој изради. 
Она је састављена у програму Excel у којој су ријечи навођене азбучним редом, а постојале су сљедеће колоне: ријеч на ијекавици, ријеч на екавици, извор и примјер у реченици. Други дио пројекта извели су студенти Електротехничког факултета у Бањој Луци, уз помоћ инжењера компаније Ланако (Исто).

\section{3. Изглед андроид и веб-апликације}

3.1. Ријечи у инфинитиву или у номинативу једнине

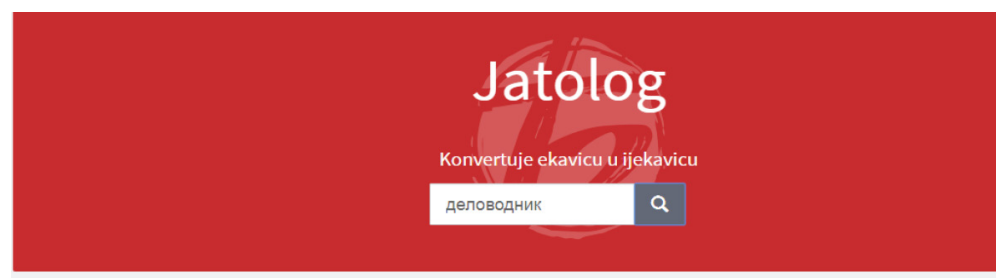

Rezultati pretrage: 1

delovodnik - djelovodnik

IzVor: "Čin prepoznavanja", Banja Luka, 2009, str. 7. (:djelovanje).

Primjeri:

Ne postoji primjer za datu riječ

Prijovigrešku

Апликација подржава латиницу и ћирилицу, као и екавицу и ијекавицу, тако да се може претраживати на три начина. Наиме, „предвиђено је да корисници укуцавају ријечи на екавици јер смо закључили да је тако најмања могућност омашке, будући да смо за писање на ијекавици морали предвидјети све могуће погрешно написане ријечи (нпр. цио - цјел - цијел - цијели), што би отежало израду апликације“ (Савић, 2018: 744). 
3.2. Падајући мени

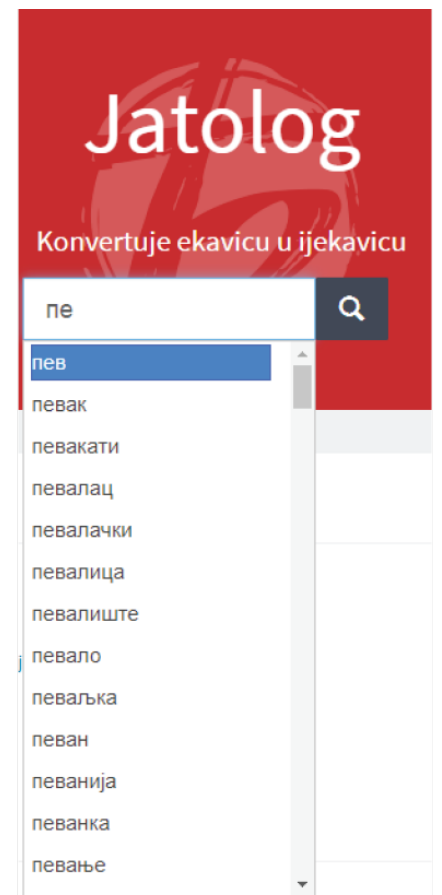

Падајући мени се отвара чим почне претрага, како би се кориснику омогућило да види и друге ријечи које садрже замјену јата, а за које можда дотад није знао. 
3.3. Најчешће претраживане ријечи

\section{- Najecešceppettaǐivane rijeci -}

operati $\rightarrow$ opievati

operati $\rightarrow$ op everti

svetlo - svijetlo

svetlo - s syjetlo

belogardejac $\rightarrow$ bjelogardejac

belogardejac $\rightarrow$ bjelogardejac

mleko $\rightarrow$ mlijekio

Svetlonosac - +syjetlonosac

\section{WLANACO}

Апликација садржи и базу најчешће претраживаних ријечи која има двоструку намјену - прво, она треба да покаже корисницима које су најфреквентније ријечи које изазивају недоумице и друго, треба да креаторима апликације пружи корисне информације које би им могле помоћи у унапређивању апликације. 


\section{4. Примјери}

Rezultati pretrage: 2

\section{opevati - opijevati}

Izvor: Godišnjak Matice srpske, Banja Luka, 2/2012, str. 420.

Primjeri:

1. Nocima je opijevala njihov susret.

Prijavi grešku

opevati - opjevati

Izvor: "Čin prepoznavanja", Banja Luka, 2009, str. 155. (:opjevavati). Primjeri:

1. Pjesnik je opjevao raj

Prijavi grešku

Примјери нису наведени за све ријечи, али је и у апликацији и у бази података остављена могућност за то. За почетак, написани су само за оне ријечи које могу изазвати недоумице. Рецимо, у случајевима да постоји разлика у ијекавским облицима свршених и несвршених глагола:

Опевати $\rightarrow$ опјевати и опијевати

Затим, ту су и оне ријечи у чијим облицима постоје очигледне семантичке разлике које корисницима могу бити или нејасне или их уопште не познају и не детектују у језику.

Озеленети : озеленити $\rightarrow$ озелењети : озеленити 
Rezultati pretrage: 1

ozeleneti-ozelenjeti

Izvor: "Čin prepoznavanja", Banja Luka, 2009, str. 107.

Primjeri:

1. Ozelenjele grane.

Prijovigrešku
Rezultati pretrage: 1

ozeleniti - ozeleniti

Izvor: "Čin prepoznavanja", Banja Luka, 2009, str. 107. (:0zelenjeti).

Primjeri:

1. Ozelenio sam svoje drvo

Prijovigrešku

3.5. Нове ријечи

KREIRANJE PREDLOŽENE RIJEČI

\section{Ekavica latinica}

ljekavica latinica

\section{Predložio}

Napomena

Izvor

\section{Primier}

Ова апликација има и могућност додавања нових ријечи, али искључиво истим поступком који је кориштен приликом њене израде. Наиме, корисници би морали укуцати ријеч и на ијекавици и на екавици, извор из које је ријеч ексцерпирана, као и примјер у реченици (Савић, 2018). 


\section{4. Закључак}

У раду је дат преглед израде мобилне и веб-апликације

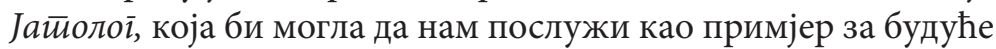
повезивање језика и дигиталних технологија, а у овом послу нам се врло лако може придружити и сектор креативне индустрије. У окружењу смо видјели примјер у којем је писменост удружена са маркетингом и то тако што корисник „зарађује“ бодове за сурфање интернетом одговарајући на питања у вези језика (Dnevnik.hr). Осим приватно-јавног партнерства, свједоци смо постојања и многих глобалних и свјетских пројеката чији је циљ дигитализација језика, а у многима од њих учествују и стручњаци из Србије. Међутим, и даље на овом пољу постоје многе нејасноће и недостаци. Овдје ћемо навести само неке.

Будући да се ради о интердисциплинарном подручју рада, за које у Републици Српској још не постоје стручњаци, најприје је потребно едуковати и професоре српског језика али и ИТ инжењере не само о потреби дигитализације језика, него и о основним идејама и алатима за тај посао. Надаље, видјели смо да у стратешком документу још увијек није предвиђена дигитализација језика, тако да би било потребно направити план дјеловања у оквиру којег би се нашле све заинтересоване стране али и који би нам омогућио увид у највеће предности и мане ових пројеката, у методологију рада, подручја језика које треба дигитализовати итд. Поред тога, српски језик треба посматрати у његовом интегралном облику - дакле укључујући и језик који се говори у на другим подручјима.

Дигитализација је сигурна будућност, али је и мач са двије оштрице - са једне стране, она може довести до још већег слабљена утицаја малих језика и ширења комуникативног простора великих језика, али са друге стране, дигитализација може бити и алат којим ћемо језик спасити и увести га у нову индустријску револуцију и то тако што ћемо кориштењем иновација омогућити лакше учење језика и нашим ђацима и странцима, промоцију, сарадњу лингвиста са стручњацима из других области итд. Који од ових начина 
ћемо изабрати, нажалост не зависи само од нас, него и од подршке домаћих и страних институција, сарадње са другим научницима, али и привредом.

\section{Литература}

Duško Vitas, Ljubomir Popović, Cvetana Krstev, Ivan Obradović, Gordana Pavlović-Lažetić, Mladen Stanojević, Срйски језик у gиїитиалном gобу - бијела књига, Georg Rehm, Hans Uszkoreit(уредници, editors), Springer. http://www.meta-net.eu/whitepapers/e-book/serbian.pdf

Александра Савић (2018), „Апликација Јайолої“, Филолоі̄, IX, 17, Бања Лука: Филошки факултет.

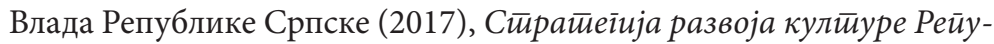
блике Срйске 2017-2022. http://www.vladars.net/sr-SP-Cyrl/ Vlada/Ministarstva/mpk/Documents/Strategija\%20razvoja\%20 kulture\%202017-2022.pdf

Удружење лектора Републике Српске, Айликација Јайолої. http:// www.jatolog.udruzenjelektorars.com/

\section{Веб-странице}

Dnevnik.hr: https://dnevnik.hr/vijesti/hrvatska/a1-lappsus-aplikacijakojom-ucite-ali-i-dobivate-vise-megabajta---559359.html

Влада Републике Српске: http://www.vladars.net/sr-sp-cyrl/Pages/ default.aspx

Министарство за научнотехнолошки развој, високо образовање и информационо друштво: http://vladars.net/sr-SP-Cyrl/Vlada/ Ministarstva/mnk/Pages/default.aspx

Министарство просвјете и културе: http://www.vladars.net/sr-SPCyrl/Vlada/Ministarstva/mpk/Pages/default.aspx

Форум о ћирилици: http://www.maticasrpska.org.rs/forumu-o-cirilitsi-u-republitsi-srpskoj/ 


\title{
Aleksandra Savić \\ Lecturers' Association of Republika Srpska \\ Independent researcher \\ aleksandra.suvira@yahoo.com
}

\section{LANGUAGE AND DIGITAL TECHNOLOGIES IN THE REPUBLIC OF SERBIA}

\begin{abstract}
The paper deals with the relationship between the Serbian language and digital technologies, as well as the current situation in the Republic of Srpska when it comes to digitization of this area. Specifically, there are indications in this $\mathrm{BiH}$ entity of a commitment to more innovative approaches to language and teaching, but we do not yet have the strategic documents governing this field. On the other hand, we are experiencing some individual efforts in the merging of new technologies and languages, and one such example is certainly the mobile and web application Jatolog developed by the Serbian Language Editors' Association, students of the University of Banja Luka and the company Lanako, and which can be an example of successful private-public partnerships.
\end{abstract}

Key words: Jatologist, application, proofreading association of Republika Srpska, Lanako, digital technologies 